\title{
Éditorial
}

\section{Leïla Choukroune}

\section{(2) OpenEdition}

12 Journals

\section{Electronic version}

URL: http://journals.openedition.org/chinaperspectives/5781

DOI: 10.4000/chinaperspectives.5781

ISSN: 1996-4617

\section{Publisher}

Centre d'étude français sur la Chine contemporaine

\section{Printed version}

Date of publication: 30 March 2012

Number of pages: 5-7

ISSN: 2070-3449

\section{Electronic reference}

Leilla Choukroune, «Éditorial », China Perspectives [Online], 2012/1 | 2012, Online since 30 March 2012, connection on 24 September 2020. URL : http://journals.openedition.org/chinaperspectives/5781 DOI : https://doi.org/10.4000/chinaperspectives.5781 


\section{Editorial}

\section{LEÏLA CHOUKROUNE*}

$\mathrm{T}$ en years ago, when commenting on the accession of China to the World Trade Organization (WTO), Mike Moore, then Director General of the Organization, was predicting "a historic moment for the WTO, for China, and for international economic co-operation." (1) Even so, none of the brilliant economic forecasts of that time was able to gauge the magnitude of the China trade revolution. (2)

\section{The great beneficiary}

Miracle or threat, China's trade growth and its impact on the world are now part of every economic conversation. (3) Evidence of this dramatic change is given by astonishing trade figures. From US\$249.2 billion in 2000, at the eve of the WTO accession, Chinese merchandise exports have increased to $\$ 1,577.8$ billion in 2010. ${ }^{(4)}$ China is exporting to every single region of the world, with a spectacular merchandise trade growth with Latin America (from $\$ 5.7$ billion in 2000 to $\$ 69.9$ billion in 2010) and Africa (from $\$ 4.9$ billion in 2000 to $\$ 58.1$ billion in 2010). Although far less impressive, the China ascendancy in trade in commercial services is also perceptible. With 4.6 percent of the world trade in commercial services in 2010, China occupies the fourth global position, right after India and before Japan. ${ }^{(5)}$ While Chinese exports are skyrocketing, Chinese merchandises imports are also steadily increasing (from $\$ 7.2$ billion in 2000 to $\$ 106.9$ billion in 2010). China's imports in natural resource products are indeed booming, and so are its investments as a strategic need to sustain its growth. ${ }^{(6)}$ Moreover, the trade deficit registered by the EU or the US should be put in perspective, as it is partly due to the exportation of goods produced in China by American or European subsidiaries. Not to mention that the China trade greatly benefits from an exchange rate policy perceived as unfair by its main trading partners, including emerging economies such as Brazil, which has recently submitted a proposal to the WTO arguing in favour of contingent protection measures against imports from countries favoured by undervalued exchange rates. ${ }^{(7)}$

Despite all these analytical precautions, one can only resort to a now commonly accepted analysis, that of China trade hyper-growth and possible dominance to come. As shown by the table reproduced below, China will, in all likelihood, dominate the trade universe in the next 20 years.

\section{Countries' share of world trade and GDP growth}

According to these economic forecasts, China, which accounted for 10 percent of the world trade in merchandise in 2010, will account for nearly 15 percent by 2030 , and its trade will represent more than double that of the US and quadruple that of Germany. This dynamism will both benefit from and participate in the dramatic rise of intra-Asian trade to such an extent that the gravity centre of trade will shift from the US and Europe to Asia. ${ }^{(8)}$

But what else would this imply for China and the world? In early 2002 just as China joined the WTO, the CEFC released two special issues of China
Perspectives dedicated to this already fascinating evolution. Ten years later, a number of leading trade experts from academia and practice have accepted our invitation to reflect upon China's participation in the WTO and how this has changed - or not - the Chinese legal framework and practice as well as international trade and the Organization itself.

\section{A state capitalist in global trade}

As demonstrated in this special issue, a few trends are already perceptible: intensified business concerns ${ }^{\left({ }^{9}\right)}$ over an uneven playing field generated by the unsatisfactory implementation of key WTO commitments such as transparency, uniform application, and judicial review (Leïla Choukroune, Hubert Bazin), increasing tensions over the protection of intellectual property rights (Bryan Mercurio, Rogier Creemers), impaired market access (Hubert Bazin), societal concerns in relation to the "human dimension of international trade" and, for instance, the food safety issue (Denise Prevost), access to information and censorship (Rogier Creemers), export restrictions and increase of the number of complex trade disputes (Leïla Choukroune), and the role played by China in global trade negotiations (Henry Gao).

All these concrete trade cases have a direct impact on China and the world, but if China has become a global trader it also remains a "state cap-

Leïla Choukroune (Doctorate in International Law from Paris Sorbonne Law School, Lawyer Paris Bar) teaches international economic law at Maastricht University. She is Deputy Director of the Institute for Globalization and Economic Regulation (IGIR). Her research deals with the interactions between trade, investment and human rights with a special interest for the emerging world and Asia, China and India in particular, where she has lived and visits very frequently.

1. See Leïla Choukroune, Introduction to China Perspectives Special Issue on China and the WTO, no. 40, March-April 2002

2. See generally China Perspectives, Special Issues no. 40 and 41 on China and the WTO, particularly the article by Jean-François Huchet, "China's Economic Wager on the WTO: Realities, Myths and Unknown Factors," no. 41, pp. 4-13.

3. See EU-China Trade Relations, a study coordinated by Leïla Choukroune and authored by Denise Prevost, Jean-François Huchet, Rogier Creemers, and Leila Choukroune for the European Parliament Directorate General for External Policies, Policy Department, presented at the EU Parliament on 11 October 2011, www.maastrichtuniversity.nl/web/Main/Sitewide/Content/IGIRFellowLeila ChoukrounePresentsStudyOnEUChinaTradeRelationsToEuropeanParliament.htm (consulted on 6 March 2012).

4. See WTO 2011 International Trade Statistics.

5. Ibid., p. 157

6. For a very thorough overview of the tensions at stake between exports and the greater need for imports, see Aaditya Mattoo and Arvind Subramanian, China and the World Trading System, World Bank Policy Research Paper 5897, December 2011.

7. "The bearing of wide currency fluctuations on the delicate balance of commitments and concessions resulting from negotiations at the WTO must be better understood and be properly dealt with. Brazil is suggesting that the WGTDF (Working Group on Trade, Debt and Finance) examines available tools and trade remedies in the existing multilateral system, if any, to compensate for or otherwise redress those currency fluctuations that may impair commitments undertaken by Members in successive rounds of negotiations. In addition, addressing that issue may help prevent the overstretching of multilateral trade rules as regards, for instance, provisions on safeguards, antidumping, subsidies and countervailing measures, as well as bound tariffs" ("The relationship between exchange rates and international trade," submission by Brazil,WT/WGTDF/W/56, 20 September 2011).

8. Arvind Subramanian, Eclipse: Living in the Shadow of China's Economic Dominance, Washington, Peterson Institute of International Economics, 2011, and Aaditya Mattoo and Arvind Subramanian, China and the World Trading System, op. cit.

9. See European Chamber of Commerce in China, Europe Business in China, Business Confidence Survey 2011, www.europeanchamber.com.cn/view/media/publications (consulted on 25 February 2012). 
Table 1 -Countries' share of world trade and GDP growth

\begin{tabular}{|l|c|c|c|c|c|c|c|}
\hline \multirow{2}{*}{ Country/group } & \multicolumn{2}{|c|}{ Trade (US\$ billion) } & Growth & \multicolumn{2}{c|}{ Share in world trade } & \multicolumn{2}{c|}{ Trade to GDP } \\
\hline & $\mathbf{2 0 1 0}$ & $\mathbf{2 0 3 0}$ & $\mathbf{2 0 1 0 - 2 0 3 0}$ & $\mathbf{2 0 1 0}$ & $\mathbf{2 0 3 0}$ & $\mathbf{2 0 1 0}$ & $\mathbf{2 0 3 0}$ \\
\hline United States & 3,224 & 5,827 & $3.0 \%$ & $10.6 \%$ & $7.3 \%$ & $22.0 \%$ & $24.3 \%$ \\
\hline Japan & 1,460 & 2,586 & $2.9 \%$ & $4.8 \%$ & $3.2 \%$ & $26.8 \%$ & $35.2 \%$ \\
\hline China & 2,972 & 11,972 & $7.2 \%$ & $9.8 \%$ & $15.0 \%$ & $50.6 \%$ & $53.4 \%$ \\
\hline India & 539 & 3,907 & $10.4 \%$ & $1.8 \%$ & $4.9 \%$ & $35.1 \%$ & $46.4 \%$ \\
\hline Korea & 892 & 2,617 & $5.5 \%$ & $2.9 \%$ & $3.3 \%$ & $88.5 \%$ & $120.5 \%$ \\
\hline Brazil & 384 & 991 & $4.9 \%$ & $1.3 \%$ & $1.2 \%$ & $18.3 \%$ & $21.4 \%$ \\
\hline Indonesia & 136 & 993 & $10.5 \%$ & $0.4 \%$ & $1.2 \%$ & $19.2 \%$ & $34.0 \%$ \\
\hline Russia & 648 & 890 & $1.6 \%$ & $2.1 \%$ & $1.1 \%$ & $44.3 \%$ & $43.3 \%$ \\
\hline Germany & 2,318 & 2,918 & $1.2 \%$ & $7.6 \%$ & $3.7 \%$ & $89.7 \%$ & $76.0 \%$ \\
\hline WORLD & $\mathbf{3 0 , 3 8 7}$ & $\mathbf{7 9 , 9 0 5}$ & $\mathbf{5 . 0} \%$ & $\mathbf{1 0 0 . 0} \%$ & $\mathbf{1 0 0 . 0} \%$ & $\mathbf{4 8 . 7} \%$ & $\mathbf{5 7 . 2} \%$ \\
\hline
\end{tabular}

Source: Arvind Subramanian, Eclipse: Living in the Shadow of China's Economic Dominance, Washington, Peterson Institute of International Economics, 2011.

italist" and as such an intriguing partner, ${ }^{(10)}$ if not a direct cause of anxiety for the international community. The China miracle is also that of an unparalleled country that has been able to abide by the rules while playing with them. The apparent conformity of the Chinese model with international rules hides a much more complex situation in which the state is ambiguously engaged in the economy. This may not be completely new, as many other countries, including the EU and the US, have by no means embraced a pure liberal capitalist model, but the China paradigm nevertheless remains unique in its reach and implications. Indeed, over the past 30 years, China's GDP has grown at an average rate of 9.5 percent a year and its international trade by 18 percent in volume. ${ }^{(11)}$ From holding shares in the biggest companies to SOEs' foreign direct investment in strategic resources and specific loans and currency policies, the Chinese state is present in every sector and at every level of the economy. So why is this rise coinciding with a certain liberal capitalism crisis, and what does it tell China's competitors? It may be that the current policies of the US and the EU and, for instance, their industrial policies have to be revised in a critical manner against the free market dogma of the 1980s and 1990s. The world will have to count
China in, and so will it have to reconsider the role of the state in the economy in order to better balance different actors' interests and create a level playing field for Beijing and other emerging economies. In doing so, the WTO will matter, but so will the many Foreign Trade Agreements (FTA) (12) that countries are now adopting on a bilateral and regional basis. The complexity of the trade scenario will only strengthen the need for political vigilance and clarification of the state's objectives for economic development. As long as China's trade growth will not benefit all equally, and the Chinese population to start with, this transformation will demand not only admiration, but also legitimate concern.

10. See "The Rise of State Capitalism, The Emerging World's New Model," The Economist, January 2012, pp. 21-27.

11. For further details, see Table 2 - China Main Economic Indicators.

12. See Wang Guiguo, "China's FTAs: Legal Characteristics and Implications," American Journal of International Law, vol. 105, no. 3, July 2011.

\section{Table 2 - China Main Economic Indicators}

\section{BASIC INDICATORS}

\begin{tabular}{|l|l|}
\hline Population (thousands, 2010) & 1338300 \\
\hline GDP (million current US\$, 2010) & 5878629 \\
\hline GDP (million current PPP US\$, 2010) & 10084764 \\
\hline Current account balance (million US\$, 2010) & 305370 \\
\hline Trade per capita (US\$, 2008-2010) & 2135 \\
\hline Trade to GDP ratio (2008-2010) & 55.4 \\
\hline & 2010 \\
\hline Real GDP (2005=100) & 170 \\
\hline Exports of goods and services (volume, 2005=100) & 180 \\
\hline Imports of goods and services (volume, 2005=100) & 168 \\
\hline
\end{tabular}

\begin{tabular}{|l|c|c|}
\hline Rank in world trade, 2010 & Exports & Imports \\
\hline Merchandise & 1 & 2 \\
\hline excluding intra-EU trade & 2 & 3 \\
\hline Commercial services & 4 & 3 \\
\hline excluding intra-EU trade & 3 & 3 \\
\hline
\end{tabular}

Annual percentage change

\begin{tabular}{|c|c|c|}
\hline $\mathbf{2 0 0 5}-\mathbf{2 0 1 0}$ & $\mathbf{2 0 0 9}$ & $\mathbf{2 0 1 0}$ \\
\hline 11 & 9 & 10 \\
\hline 12 & -10 & 25 \\
\hline 11 & 4 & 17 \\
\hline
\end{tabular}


TRADE POLICY

\begin{tabular}{|l|l|}
\hline WTO accession & 11 December 2001 \\
\hline Trade Policy Review & 31 May, 2 June 2010 \\
\hline GPA accession & Observer \\
\hline
\end{tabular}

\begin{tabular}{|l|c|c|}
\hline \multicolumn{2}{|l|}{ Tariff binding coverage (\%) } & \multicolumn{2}{l|}{100} \\
\hline MFN tariffs & Final bound & Applied 2010 \\
\hline Simple average of import duties & 10 & 9.6 \\
\hline All goods & 15.7 & 15.6 \\
\hline Agricultural goods (AOA) & 9.2 & 8.7 \\
\hline Non-agricultural goods & 0 & 0.5 \\
\hline Non ad-valorem duties (\% total tariff lines) & & \\
\hline MFN duty free imports (\%, 2009) & 0.9 & 0.9 \\
\hline in agricultural goods (AOA) & & 50.6 \\
\hline in non-agricultural goods & & 93 \\
\hline Services sectors with GATS commitments & & \\
\hline
\end{tabular}

\begin{tabular}{|l|c|}
\hline MERCHANDISE TRADE & 2010 \\
\hline Merchandise exports, f.o.b. (million US\$) & 1577824 \\
\hline Merchandise imports, c.if. (million US\$) & 1395099 \\
\hline
\end{tabular}

\begin{tabular}{|l|c|}
\hline & $\mathbf{2 0 1 0}$ \\
\hline Share in world total exports & 10.36 \\
\hline Breakdown in economy's total exports & \\
\hline By main commodity group (ITS) & 3.3 \\
\hline Agricultural products & 3 \\
\hline Fuels and mining products & 93.6 \\
\hline Manufactures & \\
\hline By main destination & 19.7 \\
\hline 1. European Union (27) & 18 \\
\hline 2. United States & 13.8 \\
\hline 3. Hong Kong, China & 7.7 \\
\hline 4. Japan & 4.4 \\
\hline 5. Korea, Republic of & \\
\hline
\end{tabular}

\begin{tabular}{|l|c|}
\hline COMMERCIAL SERVICES TRADE & $\mathbf{2 0 1 0}$ \\
\hline Commercial services exports (million US\$) & 170248 \\
\hline Commercial services imports (million US\$) & 192174 \\
\hline
\end{tabular}

\begin{tabular}{|l|c|}
\hline & $\mathbf{2 0 1 0}$ \\
\hline Share in world total exports & 4.61 \\
\hline Breakdown in economy's total exports & \\
\hline By principal services item & 20.1 \\
\hline Transportation & 26.9 \\
\hline Travel & 53 \\
\hline Other commercial services & \\
\hline
\end{tabular}

\section{INDUSTRIAL PROPERTY}

Patent grants by patent office, 2009

\begin{tabular}{|c|c|c|}
\hline Residents & Non-residents & Total \\
\hline 65391 & 63098 & 128489 \\
\hline
\end{tabular}

Source: http://stat.wto.org/CountryProfiles/CN_E.htm
Tariffs and duty free imports

\begin{tabular}{|c|c|c|c|}
\hline \multicolumn{3}{|c|}{ Contribution to WTO budget $(\%, 2011)$} & 6.878 \\
\hline \multicolumn{4}{|c|}{ Import duties collected $(\%, 2006-2008)$} \\
\hline \multicolumn{3}{|c|}{ in total tax revenue } & 3 \\
\hline \multicolumn{3}{|c|}{ to total imports } & 1.9 \\
\hline \multicolumn{4}{|c|}{ Number of notifications to WTO and measures in force } \\
\hline \multicolumn{3}{|c|}{ Outstanding notifications in WTO Central Registry } & 12 \\
\hline \multicolumn{3}{|c|}{ Goods RTAs - services EIAs notified to WTO } & 9-Aug \\
\hline \multicolumn{3}{|c|}{ Anti-dumping (30 June 2010) } & 119 \\
\hline \multicolumn{3}{|c|}{ Countervailing duties (30 June 2010) } & 1 \\
\hline \multicolumn{3}{|c|}{ Safeguards (22 October 2010) } & 0 \\
\hline \multicolumn{4}{|c|}{ Number of disputes (complainant - defendant) } \\
\hline \multicolumn{3}{|c|}{ Requests for consultation } & Aug-22 \\
\hline \multicolumn{3}{|c|}{ Original panel / Appellate Body (AB) reports } & 4-May \\
\hline \multicolumn{3}{|c|}{ Compliance panel / AB reports (Article 21.5 DSU) } & $0-0$ \\
\hline \multicolumn{3}{|c|}{ Arbitration awards (Article 22.6 DSU) } & $0-0$ \\
\hline \multirow{3}{*}{$\begin{array}{l}\text { Annual } \\
\text { percentage } \\
\text { change }\end{array}$} & $2005-2010$ & 2009 & 2010 \\
\hline & 16 & -16 & 31 \\
\hline & 16 & -11 & 39 \\
\hline
\end{tabular}

\begin{tabular}{|l|c|}
\hline & $\mathbf{2 0 1 0}$ \\
\hline Share in world total imports & 9.06 \\
\hline Breakdown in economy's total imports \\
\hline By main commodity group (ITS) & \\
\hline Agricultural products & 7.8 \\
\hline Fuels and mining products & 26.7 \\
\hline Manufactures & 64.1 \\
\hline By main origin & \\
\hline 1. Japan & 12.6 \\
\hline 2. European Union (27) & 12 \\
\hline 3. Korea, Republic of & 9.9 \\
\hline 4. Taipei, Chinese & 8.3 \\
\hline 5. China & 7.6 \\
\hline
\end{tabular}

\begin{tabular}{|l|c|c|c|}
\hline $\begin{array}{l}\text { Annual } \\
\text { percentage } \\
\text { change }\end{array}$ & $\mathbf{2 0 0 5 - 2 0 1 0}$ & $\mathbf{2 0 0 9}$ & $\mathbf{2 0 1 0}$ \\
\hline & 18 & -12 & 32 \\
\hline
\end{tabular}

\begin{tabular}{|l|c|}
\hline & $\mathbf{2 0 1 0}$ \\
\hline Share in world total imports & 5.47 \\
\hline Breakdown in economy's total imports \\
\hline By principal services item & \\
\hline Transportation & 32.9 \\
\hline Travel & 28.6 \\
\hline Other commercial services & 38.5 \\
\hline
\end{tabular}

